\title{
ISPO CERTIFICATION AND INDONESIAN OIL PALM COMPETITIVENESS IN GLOBAL MARKET SMALLHOLDER CHALLENGES TOWARD ISPO CERTIFICATION
}

\author{
Sertifikasi Ispo dan Daya Saing Kelapa Sawit Indonesia di Pasar Global \\ Tantangan Perkebunan Rakyat Menghadapi Sertifikasi ISPO
}

\author{
Sakti Hutabarat ${ }^{12}$ \\ ${ }^{1}$ Department of Agribusiness, Faculty of Agriculture, University of Riau \\ Jl. HR Soebrantas km 12,5, Kampus Binawidya, 28293, Pekanbaru, Indonesia \\ ${ }^{2}$ Plant Production System Group, Wageningen University \\ Droevendaalsesteeg 1, 6708PB Wageningen, The Netherlands \\ shutmail@yahoo.com \\ and sakti.hutabarat@lecturer.unri.ac.id
}

Diterima tanggal : 29 Agustus 2017 ; Disetujui tanggal : 30 November 2017

\begin{abstract}
Certification becomes a prerequisite for tradable products to get legality and access to global market. Each tradable product can choose certificate according to its market destination. However, the application of certification standards are very low in both international (RSPO and ISCC) and domestic (ISPO) standards. This study was focused on the ISPO certification. How large is the gap between current practices and ISPO standard? What are factors that affect adoption of ISPO certification? Does ISPO deliver more access to market for oil palm smallholders? Do smallholders have adequate capacity to meet ISPO standard? These questions have been assessed and discussed in this paper to find answer and alternative way out for smallholders to meet the ISPO standard. The objective of this study is to assess capacity and willingness of oil palm independent smallholders to meet the standard of ISPO certification. This study was conducted in Pelalawan District, Riau Province using a survey method. The result shows that a number of barriers are faced by smallholders to obtain ISPO certification while the opportunity to get better access to local and global market is still uncertain. The adoption of ISPO certificate was influenced by farmers' knowledge on agricultural practices, business legality, household income, and land-size.
\end{abstract}

Keywords : certification, competitiveness, palm oil, smallholder

\section{INTISARI}

Sertifikasi telah menjadi suatu prasyarat bagi produk-produk komersial untuk mendapatkan legalitas dan akses ke pasar global. Setiap produk yang diperdagangkan dapat memilih sertifikat sesuai dengan tujuan pemasaran. Namun, penerapan standar-standar sertifikasi masih sangat rendah baik standar international (RSPO dan ISCC) dan nasional (ISPO). Studi ini difokuskan pada sertifikasi ISPO. Sejauh mana kesenjangan antara praktek budidaya saat ini dan standar ISPO? Apa faktor-faktor yang mempengaruhi penerapan sertifikasi ISPO? Apakah ISPO memberikan akses pasar yang lebih baik pada pekebun kelapa sawit? Apakah pekebun memiliki kapasitas yang memadai untuk menerapkan standard ISPO? Pertanyaan- 
pertanyaan tersebut telah dikaji dan dibahas dalam tulisan ini untuk menemukan jawaban dan alternatif solusi bagi pekebun dalam memenuhi standar ISPO. Tujuan studi ini adalah untuk mengukur kapasistas dan keinginan pekebun kelapa sawit swadaya untuk memenuhi standar sertifikasi ISPO. Studi ini telah dilaksanakan di Kabupaten Pelalawan, Provinsi Riau dengan menggunakan metode survei. Hasil penelitian memperlihatkan bahwa sejumlah tantangan dihadapi oleh pekebun kelapa sawit untuk mendapatkan sertifikat ISPO sementara peluang untuk mendapatkan akses yang lebih baik pada pasar lokal dan global masih belum jelas. Adopsi sertifikat ISPO bergantung dari pengetahuan pekebun tentang praktek budidaya, legalitas usaha perkebunan, pendapatan rumah tangga, dan luas kepemilikan lahan.

Kata kunci : sertifikasi, daya saing, minyak sawit, pekebun rakyat

\section{INTRODUCTION}

Transforming the market to make sustainable products become a trend in global supply chains. Certification is one of global market change for tradable products. Started by organic movement in 1940s, then followed by International Federation of Organic Agriculture Movements (IFOAM) in 1970, Fairtrade in 1988, Storage Area Network (SAN) in 1991, Forest Stewardship Council (FSC) in 1993, International Organization for Standardization (ISO) 14001 in 1996, Roundtable on Sustaianble Palm Oil (RSPO) in 2004 and International Sustainability \& Carbon Certificate (ISCC) in 2010. The latest certification program was launched by Indonesian Ministry of Agriculture in 2011, the Indonesian Sustainable Palm Oil (ISPO). The regulation was revised in the Minister of Agriculture Regulation No. 11/2015.

The standard of ISPO is mandatory for plantation companies, plantations only with no mill, and mills with no plantation while it is still voluntary for scheme and independent smallholders.
Choosing appropriate certification program for a tradable product in the global market could be a dilemma for Indonesian producers, particularly for palm oil and its derivatives products. Indonesia is the leading palm oil producers in the global market that provides $52 \%$ of world supply of palm oil products. Indonesia exports more than $70 \%$ of palm oil to international market which tend to apply RSPO or ISCC certification. At the same time, palm oil industry in Indonesia must have ISPO certificate.

In the future, ISPO will be a mandatory certification for oil palm smallholders. Based on the Minister of Agriculture Regulation No. 98/2013, Oil palm smallholders are growers that have land size less than 25 ha. The majority of Indonesian smallholders have only less than 4 ha. The business scale is not adequate to cover modern agricultural practices with certification standards. Therefore, smallholders must establish group certification such as Village Cooperative (called Koperasi Unit Desa/KUD) and 
Farmer Group (called Gabungan Kelompok

Petani/ GAPOKTAN) or association) to reach a minimum business scale to be certified.

Certification is a procedure by which a third party (certification institution/ certification body) offers written assurance that a product, process or service is in conformity with certain standards. Certification is a documented agreements which specify standards (principles, criteria, and indicators) as a rules or guidelines that must be complied by actors in a product supply chains for sustainable products .

Certification system includes standards, certification, accreditation, and labelling. Standard consists of principles, criteria, and indicators that need to be applied with certain procedures. Certification is conducted to ensure that the standards are being applied correctly. Accreditation for certification body is important to make sure that certification system is working appropriately. Finally, the compliance to standard could be represented by labelling (brands or logos) (FAO, 2014; Gawron \& Theuvsen, 2010).

Sustainable certification scenario includes institutionalization of private governance arrangement that allows actors in the market play the games by themselves, improve transparency and accountability by creating complementary between private and state regulations, and enhancing coherence of sustainability standard between public and private sectors (Arifin, 2016).

The need of certification to get better access to global market has encouraged companies, millers, processors and traders to make commitment to produce sustainable products. The growth rate of certified products has increased to become more than $40 \%$ outperforming growth of conventional commodity markets in 2012.

However, process to comply with standard and obtain certificate is not simple, particularly for oil palm smallholders since agricultural practices and plantation management practices are often conducted traditionally for many years. Certification requires attention, capital, labour and time. Smallholders need additional costs to meet the standards while additional yield and revenue might be uncertain (Hutabarat, Slingerland, Rietberg, et al., 2017).

Studies have been conducted to show the impact of global changes through certification, for example Fair trade on coffee (Bacon et al., 2008; Barham et al., 2011; Raynolds et al., 2007), Cacao (Aidoo \& Fromm, 2015; Gockowski et al., 2013), cotton (Kaminski et al., 2011; Makita, 2012), and horticulture (Kuwornu et al., 2013; Lemeilleur, 2013; Ouma, 2010). Certification could improve yield (Lee et al., 2014; Weber, 2011) and reduce risk on farmers' income (Bacon, 2005; Blackman \& Jorge, 2011). However, 
the revenue received by farmers are mostly from increasing yield but not price premium (Barham \& Weber, 2012). In contrast, Beuchelt and Zeller (2011) found that revenues from technological changes in certification scheme often cannot compensate the additional cost involved in the process of production.

Few studies were focused on certification on oil palm smallholders, for example study on sustainability certification and oil palm smallholders' livelihood (Hidayat et al., 2015), transforming local institution on smallholders' organization (Bitzer et al., 2013; Prodinger et al., 2015), and certifying sustainability for oil palm smallholder (Amekawa, 2010; SilvaCastaneda, 2012). Studies on the impact of certification have been started since the first RSPO certified oil palm smallholders was obtained by Amanah Association on July 2013 (Brandi et al., 2015; Calil, 2013; Christin et al., 2015; Harianja et al., 2015; Lee et al., 2011). Currently, there are only four farmer groups in Indonesia that obtained RSPO certificate: Amanah Independent Oil Palm Smallholders Association at Ukui Subdistrict, Riau Province; GAPOKTAN Tanjung Sehati at Tabir Selatan Subdistrict, Jambi Province; Yayasan Sapta Tunggal Mandiri at Lempuing Jaya Subdistrict, South Sumatera; and Forum Petani Swadaya Merlung Renah at Renah Mendaluh
Subdistrict, Jambi Province. There are still some groups in the process of RSPO certification, for example, GAPOKTAN Kopau Jaya at Sengingi Tengah and Mandiri Association at Kuantan Hilir, Riau Province. Amanah Association is also the first group certification that obtain ISPO certificate on Februay 2017.

\section{ISPO Certification System}

This study was focused on the ISPO. ISPO was claimed as an instrument to enhance economy of Indonesia. ISPO was mandatory for oil palm industry operated in Indonesia to ensure sustainability production. ISPO that adopted Indonesian rules and regulations is also take into account international principles of oil palm sustainable production. The differences between ISPO and RSPO are the criteria related to High Conservation Values (HCV), Free, Prior and Informed Consent (FPIC), and New Planting Procedures (NPP).

Companies that submit an application for ISPO must already have been assessed in accordance to Minister of Agriculture Regulation No. 2/2009 on guideline for plantation business assessment on legal permit, plantation management, processing, social economy, environment and reporting. The pre-certification prerequisite classify plantation into five categories. Plantations that are in Class I, II, and III are eligible to apply for ISPO certification. 
ISPO Sustainability Principles consists of seven principles: First, the legality of plantation business; Second, plantation management; Third, protection to the utilization of primary forest and peatlands; Fourth, environtmental management; Fifth, responsibility of workers; sixth, responsibility of the social and economic empowerment; and seventh, continuous business improvement.

The principles of ISPO standard are different amongst different type of producers. Large scale operators must comply with seven principles while scheme smallholders have to meet six principles and independent smallholders four principles.

\section{The Role of Government}

In a competitive market, market coordination is performed by private sectors. Private actors in palm oil supply chain play the game while the government facilitates the rule of the game. The role of government has been implemented through the establishment a number of regulations (Laws, Government Regulations, President Regulation, Minister Regulation, etc.). In the late 1970s, there were Ministry of Agriculture Decree No 695/1979, Minister of Agriculture Decree No 310/1981, and Minister of Agriculture Decree No $182 / 1983$. Based on these regulations the government established special team to take care of all NES projects and Loan PMU. Then. the government launched Minister of
Agriculture Decree No 668/1985 regarding General Rules for Implementation of Estate Crops Project. The Nucleus Estate Smallholders (NES) or Perusahaan Inti Rakyat (PIR) Project has been extended to establish PIR Khusus (NES Special), PIR Lokal (NES Local), PIR TRANS (NES TRANS), PIR KKPA (NES KKPA) and Self-Sustained NES.

In 1990s, government realized that another important aspect in developing oil palm industry is sustainability which comprises of environmental, social and economic aspects. These aspects need changes in system and management of oil palm production from farm-gate to consumers and/or from upstream to downstream (Manggabarani, 2009). The development of oil palm industry (from upstream to downstream) needs regulations as institutional environment that plays as the rule of games.

There are at least 108 regulations have been established to promote development of oil palm industry including 23 Laws, 21 Government Regulations, 3 Presidential Instructions, 3 Presidential Decrees, 32 Ministry Regulations, 16 Ministry Decrees, and other Government Agency Decrees and Guidelines. All of these regulations were established and controlled by various government agencies at different levels (national, provincial and regencies).

The government has applied the following regulations to support the 
development of oil palm industry that covers all stakeholders in the supply chain: Law No 12/1992 regarding Cultivation System, Law No 25/1992 regarding Cooperative, Law No 23/1997 regarding Environmental Management, Law No 41/1999 regarding Forestry.

The vast forest fires in late 1990s has motivated government to create more laws and regulations related to environmental management including Law No 18/2004 regarding Estate Crops, Minister of Agriculture Regulation No 26/2007 on Guideline of Licensing of Estate Crops Business, Minister of Agriculture Decree No. 486/2006 on Guideline of the Classification of Estate Crops Companies, Guideline of Land Opening Without Fire and Guideline of Cultivation of Oil Palm, and Minister of Agriculture Regulation No 14/2009 on Guideline of Utilization of Peat Land for Oil Palm Cultivation.

In 2000s, revitalization of estates crops was launched to improve NES and related scheme. Revitalization was established to accelerate oil palm smallholders performance. Revitalization program was based on: Minister of Agriculture Regulation No. 33/2006 regarding the Estate Crops Development through Estate Crops Revitalization Program, Minister of Finance Regulation No 117/2006, Minister of Forestry Regulation No P.26/2007, and Minister of Agriculture Decree No 438/2007.
In the last decade, when more pressure on oil palm industry, the government of Indonesia revised and issued a number of laws and regulations including Law No. 19/2013 regarding Protection and Empowerment of Farmers, Law No. 39/2014 regarding Estate Crops, Government Regulation No. 27/2012 regarding Environmental Permit, Government Regulation No. 71/2014 and Government Regulation No. 57/2016 regarding Protection and Management of Peatland Ecosystem, Minister of Agriculture Regulation No. 19/2011 and No. 11/2015 regarding ISPO, Minister of Agriculture Regulation No. 14/2013 regarding Guideline of Determination of Purchase Price of FFB, Minister of Agriculture Regulation No. 82/2013 regarding Empowerment of Kelompok Tani (POKTAN) and Gabungan Kelompok Tani (GAPOKTAN), Minister of Agriculture Regulation No. 98/2013 regarding Guideline of Estate Permit, Minister of Agriculture Regulation No. 18/2016 regarding oil palm replanting, and Minister of Agriculture Regulation No. 67/2016 regarding Empowerment of Farmers' Organization.

These regulations show that the rule of government is very important in promoting sustainable oil palm production far before the establishment of RSPO and ISPO. There are various government agencies involved in assuring that production of oil 
palm is conducted in a sustainable way such as Ministry of Agriculture, Ministry of Forest, Ministry of Environment, Ministry of Cooperative and Small Business, Ministry of Finance, National Land Agency, Provincial Government, and District Government.

The government through various government agencies has established regulations to make sure that all activities in oil palm product and oil palm derivative is produce sustainably. The regulations manage and organize business license, land use, good agricultural practices, good handling practices, good manufacturing practices, prohibition of the use of fire in land preparation, obligation to conduct Environmental Impact Analysis, and others.

All of these regulations reflect that Government of Indonesia is aware and committed to sustainable development. Many government agencies have proactively issued regulations and policies that support every principle and criteria in promoting sustainable oil palm production from upstream to downstream.

The development of oil palm industry has been implemented to improve the welfare of the nation, but it must take into account various issues in the world community. The development of oil palm in Indonesia has also been in accordance with the principles of RSPO. Participation of Indonesia in promoting sustainable production of oil palm is also reflected by the establishment of Indonesia Sustainable Palm Oil (ISPO).

However, the study found harmonisation amongst regulations and agencies plus weaknesses on law enforcement led to destroy market coordination. The implementation of ISPO could be ineffective if there is distrust from stakeholders particularly foreign actors in the global supply chains.

Based on the condition described, the research questions of this study are how large is the gap between current practices and ISPO standard; what are factors that affect adoption of ISPO certification; Does ISPO offers better access to market for oil palm smallholders? Do farmers have capacity to fullfil the certification standard? This study was aimed to assess capacity and willingness of oil palm smallholders to meet the standard of ISPO certification. The study discuss prospects and challences faced by oil palm smalholders towards ISPO certification.

\section{METHODS}

This study was conducted in Pelalawan and Kampar Districts, Riau Province. Data collected consist of smallholders' profile, plantation performance, good agricultural practices, best management practices, and other data related to ISPO Principles and Criteria. Data were collected from samples of farmers, Internal Control System (ICS), group manager, company's extension worker and local government agencies. 
The study assessed two types of smallholders: scheme smallholders and independent smallholders. Smallholders are farmers who grow oil palm with or without other crops using family labour, the plantation provide main source of household income in a land size less than 25 ha (ISPO) or 50 ha (RSPO). Scheme smallholders are farmers who join farmer group that has collaboration or partnership with estate company in a scheme called Nucleus Estate Smallholders (NES) or Perusahaan Inti Rakyat (PIR). In this partnership the farmers are called nucleus or plasma while the partnership company is called estate company. This partnership model includes NES/PIR and Koperasi Kredit Primer Anggota (KKPA). Independent smallholders are farmers that operate oil palm plantation individually without partnership or support from any party. Sample of farmers were selected from oil palm smallholders (Scheme and Independent smallholders). The size of sample are 440 farmers, comprises of PIR $(n=160), \operatorname{KKPA}(n=150)$, and independent smallholders $(\mathrm{n}=130)$.

Data was analyzed using Guttman scale to assess the gap between current practices and the standard of ISPO. Gap analysis was based on Good Agricultural Practices (GAP) and Best Management Practices (BMP) which represented by principles and criteria for scheme and independent smallholders (Table 1).
Table 1. Principle \& Criteria for Smallholders

\begin{tabular}{lrr}
\hline ISPO & Scheme & \multicolumn{2}{c}{ Indipendent } \\
standard & & \\
\hline Principles & 6 & 4 \\
Criteria & 22 & 18 \\
Indicators & 69 & 45 \\
\hline
\end{tabular}

Source: Minister of Agriculture Regulation No. $11 / 2015$

Farmers that have high score answers means have less gap compared with the standard. The application of ISPO standard was divided into three categories: good, adequate, and bad. Number of question was determined in accordance with number of criteria, 22 criteria for scheme smallholders and 18 criteria for independent smallholders.

Assessment on each criteria was based on interval scale where highest score $(h)=5$, lowest score $(1)=1$, and number of class $(s)=3$. Interval scale $=$ $((h-1) / n)-1)$. Average sample score for each criteria:

$$
\overline{\mathrm{X}}_{\mathrm{k}}=\frac{\sum_{\mathrm{s}=1}^{\mathrm{n}} \mathrm{x}_{\mathrm{ks}}}{\mathrm{n}}
$$

where

$\bar{X}_{k}=$ average sample score for criteria-k. $X_{k s}=$ score for each sampel (s) for criteria- $\mathrm{k}$, and $\mathrm{n}=$ size of sample.

Assessment on criteria in each principles were based on interval scale where highest score ( $\mathrm{p} x \mathrm{~h})$, lowest score ( $\mathrm{p} \times 1)$, and number of class $(\mathrm{s})=3$. Scale 
of interval $=((\mathrm{p}(\mathrm{h}-1)) / \mathrm{n})-0,01)$. Average sample score for each principles:

$$
\overline{\mathrm{X}}_{\mathrm{p}}=\sum_{k=1}^{r}\left[\frac{\sum_{s=1}^{n} X_{k s}}{n}\right]
$$

where

$$
\begin{aligned}
\bar{X}_{p}= & \text { average sample score for criteria in } \\
& \text { principle-p, } \\
X_{k s}= & \text { score for sample }(\mathrm{s}) \text { in criteria }\left(\mathrm{k}_{1 \ldots \mathrm{r}}\right) \\
& \text { on principle-p, } \\
\mathrm{r} \quad= & \text { number of criteria in a principle } \\
\mathrm{n} \quad= & \text { sampel size. }
\end{aligned}
$$

Assessment on all criteria in all principles for scheme smallholders use interval where maximum score $(\mathrm{h})=22$ x 5 , minimum score $(1)=22 \times 1$, and number of class $(s)=3$. Scala of interval $=((\mathrm{h}-1) / \mathrm{n})-0,01)$. Average sample score for all criteria in all principles:

$\bar{X}=\sum_{k=1}^{r}\left[\frac{\sum_{s=1}^{n} x_{k s}}{n}\right]$

where

$\bar{X} \quad=$ average sample score for all criteria (k),

$X_{k s}=$ score for sample (s) for all criteria (k),

$\mathrm{r}=$ number of criteria,

$\mathrm{n} \quad=$ sample size .

\section{RESULTS AND DISCUSSION}

The gap between current practices and ISPO standard

The first principle of ISPO for both scheme and independent smallholders is plantation legality of oil palm smallholders. The survey shows that all scheme plantations have met the standard of legality. The legality documents for scheme smallholder have already been prepared by the partnership company before the ownership of oil palm plantations were converted to the participant farmers (Manggabarani, 2009). Scheme smallholders have land ownership certificate/Sertifikat Hak Milik (SHM) prepared by partnership company and local government. Since the land title were issued by National Land Agency/ Badan Pertanahan National (BPN), it has been guarrantied that plantation site is in appropirate location for estate crops. In contrast, most of independent smallholders have inadequate legality documents (Hutabarat, Slingerland, \& Dries, 2017). They have inadequate land title as it has been regulated in Government Regulation No. 40 year 1996 regarding HGU, HGB and Right to Use Land; no business registration/Surat Tanda Daftar Usaha Perkebunan untuk Budidaya (STD-B) regulated in Minister of Agriculture Regulation No. 98 year 2013 regarding Guideline of Licensing of Estate Crops; and no environmental impact assessment/Surat Pernyataan Pemantauan dan Pengelolaan Lingkungan (SPPL) as it has been regulated in Ministry of Environment Regulation No. 13 year 2010 regarding Environmental Monitoring 
and Management (UKL-UPL) and Statement of environmental Monitoring and Management Capability (SPPL).

At the beginning, independent smallholders cultivated oil palm using traditional community land or privateowned land. However, as they expanded their oil palm plantation, they often obtain their land from state-owned land including protected forest, production forest, and conservation forest. These areas were often without clear border signs and inadequate control by government agencies. Some farmers have low education and little knowledge of formal regulations. Regrettably, government agencies have inadequate capacity to control and manage state-owned land. Lack of coordination and harmonization amongs government agencies horizontally and vertically cause the use of state-owned land by unautorised people cannot be monitored properly.

The issue of legality may explain why independent farmers only meet $25 \%$ of the ISPO standard on Principle one compared to $86 \%$ for PIR and $85 \%$ for KKPA (Table 2).

Table 2. Score on Principle 1 (Legality of plantation)

\begin{tabular}{lrrr}
\hline $\begin{array}{l}\text { ISPO } \\
\text { standard }\end{array}$ & Independent & PIR & KKPA \\
\hline Maximum & 1300 & 1600 & 1500 \\
Actual & 330 & 1369 & 1282 \\
Percentage & $25 \%$ & $86 \%$ & $85 \%$ \\
\hline
\end{tabular}

Source: Analysis of primary data (2017)
Second principle for scheme smallholders is plantation management. The first criteria is plantation management (scheme smallholders) and plantation organization and management (independent smallholders). The subcriteria are slightly different between scheme and independent smallholders. The subcriteria for scheme smallholders consists of farmers' organization (farmer group or cooperative), overlapping with mining industry, land conflicts and compensation, and data/ information for government agencies and stakeholders. Independent smallholders have no subcriteria regarding overlapping with mining industry. The second criteria is agricultural practices and transportation which comprises of land clearing, protection on water resources, plant materials, planting on mineral land, planting on peat land, plantation maintenance, pest and disease management, harvest, fresh fruit bunches (FFB) transportation, and price setting for FFB. There is no subcriteria of water resources protection for independent smallholders.

Farmers in the scheme smallholders have been organized in farmer groups and cooperatives. Technical assistant for good agricultural practices and best management practices are supported by the partnership company. Conversely, independent smallholders run the business individually without support from any party. Technical assistants from local 
government agencies were inadequate or not exist. The organization of extension workers was design to serve all agricultural activities with various skills. There is no specific extension workers for estate crops. The study found that in some areas of independent plantations, the knowledge and skill of extension workers was not match with estate crops.

The assessment found that the gap is more than $70 \%$ while PIR and KKPA meet $69 \%$ and $72 \%$, respectively, of the ISPO standards (Table 3 ).

Table 3. Score on Principle 2 (Plantation management)

\begin{tabular}{lrrr}
\hline $\begin{array}{l}\text { ISPO } \\
\text { standard }\end{array}$ & Independent & PIR & KKPA \\
\hline Maximum & 7800 & 11200 & 10500 \\
Actual & 2330 & 7781 & 7552 \\
Percentage & $30 \%$ & $69 \%$ & $72 \%$ \\
\hline
\end{tabular}

Source: Analysis of primary data (2017)

The third principle is environmental monitoring and management consist of three criteria: environmental permit, use of fire in plantation activities, and biodiversity. Both scheme and independent smallholders have the same criteria. However, scheme smallholders do not need environmental documents or Surat Pernyataan Kesanggupan Pengelolaan dan Pemantauan Lingkungan (SPPL) as it should be available for independent smallholders. The partnership company has implemented Environmental Impact Assessment (EIA), for the company including their scheme smallholders. Nevertheless, based on Minister of Environment Regulation No. $13 / 2010$, independent smallholders must have SPPL, environmental monitoring and management document. The majority of independent smallholders do not have SPPL and many of them even do not know what is the SPPL and how to obtain this document. Therefore, in this study independent smallholder only meet $34 \%$ of this criteria (Table 4).

Table 4. Score on Principle 3 (Environmental Management)

\begin{tabular}{lrrr}
\hline $\begin{array}{l}\text { ISPO } \\
\text { standard }\end{array}$ & Independent & PIR & KKPA \\
\hline Maximum & 1,950 & 2,400 & 2,250 \\
Actual & 658 & 1,766 & 1,597 \\
Percentage & $34 \%$ & $74 \%$ & $71 \%$ \\
\hline
\end{tabular}

Source: Analysis of primary data (2017)

The fourth principle for scheme smallholders is responsibility on health and work safety. The result shows that scheme smallholders have more than 65\% compliance with Principle Four. All responsibility related to health and work safety have been provided by the partnership company. This criteria is not applicable for independent smallholders.

Principles Four for independent smallholders is continuous improvement whereas this Principle for scheme smallholders is in the Principle Six. Access to information and technology for independent 
smallholers is much lower than scheme smallholders, therefore, the capability of independent smallholder to keep update with new technology is also low (Table 5). The survey shows that farmers education on average is low and the majority of the farmers do not have adequate knowledge and skill to run oil palm plantation. Technical assistants from partnership company was only available for scheme company and not accessible for independent smallholders. Extension workers from local estate agency was generally not available for independent smallholders. The survey found that the background of extension workers vary (from foodcrops, fishery, to animal husbandry), only fews of them are focus on estate crops.

Table 5. Score on Principle 4 (Responsibility on health and work safety)

\begin{tabular}{lrrr}
\hline $\begin{array}{l}\text { ISPO } \\
\text { standard }\end{array}$ & Independent & PIR & KKPA \\
\hline Maximum & 650 & 800 & 750 \\
Actual & 130 & 518 & 566 \\
Percentage & $20 \%$ & $65 \%$ & $75 \%$ \\
\hline
\end{tabular}

Source: Analysis of primary data (2017)

The fifth principle for scheme smallholders is social responsibility and community empowerment. Smallholders and their partnership company should implement community empowerment and development such as build and/or maintain village infrastruture, improve business skill for local entrepreuner, and increase access for information. This principle is also aimed to improve community tradition and local wisdom. This principle is not obliged for independent smallholders. Currently, scheme smallholders have meet more than $60 \%$ of this standard (Table 6 ).

Table 6. Score on Principle 5 (social responsibility and community empowerment)

\begin{tabular}{lrrr}
\hline $\begin{array}{l}\text { ISPO } \\
\text { standard }\end{array}$ & Independent & PIR & KKPA \\
\hline Maximum & - & 800 & 750 \\
Actual & - & 488 & 531 \\
Percentage & - & $61 \%$ & $71 \%$ \\
\hline
\end{tabular}

Source: Analysis of primary data (2017)

The sixth principle for scheme smallholders is continuous improvement. Farmers are encouraged to update their business and cultivating skill to the latest technologies. For example, using organic inputs, harmless chemical materials for pesticide and herbicide, more effective and efficient machinary, and protection equipment. This is the standard in Principle Four for independent smallholders. PIR smallholders meet $53 \%$ of the standard while KKPA only $45 \%$ (Table 7 ).

Table 7. Score on Principle 6 (Continuous improvement to businesses)

\begin{tabular}{lrrr}
\hline $\begin{array}{l}\text { ISPO } \\
\text { standard }\end{array}$ & Independent & PIR & KKPA \\
\hline Maximum & - & 800 & 750 \\
Actual & - & 422 & 335 \\
Percentage & - & $53 \%$ & $45 \%$ \\
\hline
\end{tabular}

Source: Analysis of primary data (2017) 


\section{Factors that affect application of ISPO standard}

Scheme smallholders have better access to information, technology, input, finance and market. Good Agricultural Practices (GAP) and Best Management Practices (BMP) have already been facilitated by partnership company (Manggabarani, 2009). The development of scheme smallholders were prepared properly by cooperation amongts different government ministries (Ministry of Agriculture, Ministry of Transmigration, Ministry of forestry, and Local Government),

Independent smallholders are grown by individual farmers without any support from any stakeholder. The survey found that independent farmers do not have adequate knowledge on oil palm plantation. They also do not have adequate information on business legality and environmental management. Oil palm plantations have already occupied non-converted area including protected forest, conservation areas and peatland. Applying for ISPO certificate needs legality on land. This means that plantations must be withdrawn from those areas to obtain land ownership certificate while the growers have spent a lot of fund for the plantations. Smallscale business which was on average less than 4 ha and low productivity cause their income just around the monthly regional wage. These conditions do not give enough space for smallholders to apply for ISPO certification that need additional cost to meet the ISPO standard.

These factors were also found in the previous studies. Hutabarat, Slingerland, and Dries (2017) mention that access to information, technology, inputs, financial, and market are factors that influence the adoption of certification. Calil (2013) found that the adoption of certification standard also depends on smallholders' experience, income and cosmopolitan levels. Study by (Suharni et al. (2017)) mentioned that land size, farmers' education, farming experience, availability of farm inputs influence level of GAP application on shallot.

After establishing ISPO by Government of Indonesia, it seems that there is conflicting role between ISPO and RSPO. The establishment of ISPO creates competition between ISPO and RSPO (Wijaya \& Glasbergen, 2016). Principles and criteria in RSPO and ISPO are almost similar. The differences are related to $\mathrm{HCV}$, FPIC, and New Planting.

RSPO is voluntary in nature. It is applied to producers that would like to sell $\mathrm{CPO}$ to countries that required RSPO sustainable oil palm certification, especially EU countries. However, ISPO is mandatory. All growers and producers that operates in Indonesia must comply with ISPO standard and have ISPO certificate.

However, from business actors' point of view, the application of RSPO and ISPO 
is an additional costs that they have to pay double on the same objective. In both RSPO and ISPO certification, the business actors have to pay initial investment costs for improving their practices to meet the certification standards. Then, they have to pay for annual surveillance for auditing. In this condition, the RSPO and ISPO seems to be conflicting.

It is not necessary to have RSPO certification if the CPO is sold in domestic market and/or in certain countries such as India, China, and Pakistan. However, if the CPO is sold in EU countries which applied sustainable production, the RSPO certification is a must.

These factors explain that the adoption of ISPO certification was not easy for independent smallholders.

\section{ISPO and access to market for oil palm smallholders}

Oil palm smallholders do not have mill to process their FFB to CPO. FFB must be delivered to mills owned by company. Scheme smallholders would have better access to mill as long as they have contract partnership. However, there are many scheme smallholders that have ended the contract and free to sell their FFB to any mill. In one hand, this condition could benefit farmers because they can sell the fruit to buyers that offers the highest price. On the other hand, without any contract, it would be uncertainty for market access.
Independent smallholders do not have access to mill since most of them have no minimum weight to get "delivery order" or "DO" to mill. They have to deliver their FFB through middlemen. Eventually, they always receive lower farmgate price compared to scheme smallholders.

The majority of Indonesian CPO are exported to global market which tend to apply other certification system. European Union countries have started applying sustainable standard (RSPO certification) from December 2015 and it will be 100 percent (fully) sustainable standard by 2020. Having only ISPO certificate will not have better access to the global market since the main importer countries of Indonesian $\mathrm{CPO}$, India and China have made commitment to apply sustainable palm oil in the future.

Domestic market is an alternative market that should be considered for palm oil, particularly for downstream manufactures and biodiesel. However, these options are not straightforward since domestic market have already been saturated. Entering domestic market might reduced return of investment in a competitive market for existing manufactures while increasing subsidy could be a big challenge for biodiesel industry.

Access to the global market could be a challenge in the future if ISPO cannot be accepted in international market. There 
would be excess domestic supply which led to reduce $\mathrm{CPO}$ and FFB prices. Eventually, these condition might reduce farm income and farmers' welfare.

The ISPO obliges a partnership between smallholders and mills/company with an official business contract. This will guarantee access market to mill, technical assistant from partnership company, access to finance (banking), and access to information. The ISPO also reduce land conflicts and environmental damage.

\section{CONCLUSION AND SUGGESTION}

\section{Conclusion}

Certification is an effort to ensure that globally tradable products are produced and processed sustainably. There are many certifications or standards that have been established in the global supply chains. ISPO is one of product certificate that was created by Government of Indonesia to ensure sustainable production of palm oil. However, ISPO is not acceptable in the global market. Having ISPO certificate might not improve access to global supply chains.

Competitiveness of Indonesian palm oil and accessibility to global market are not only determined by production efficiency on resource use and production cost but also depends on product certification. The capacity of independent smallholders to meet ISPO standards is on average low due to various barriers that cannot be managed by smallholders themselves including access to information, technology, inputs, financial, and market. The adoption of ISPO certification depends on farmers' knowledge on agricultural practices, business legality, household income, and farm-size.

\section{Suggestion}

Stakeholders are encouraged to facilitate training for independent farmers to improve knowledge on agricultural practices and business legality. Farmers should be facilitated to establish organization to improve business scale and business performance. Government and private sectors should facilitate smallholders to improve their capacity and bargaining power that enhance their access to global supply chains. Government of Indonesia should create rules of game that can be adopted by local and foreign actors and accepted in the global supply chains.

\section{ACKNOWLEDGEMENT}

The research has been executed within the Interdisciplinary Research and Education Fund (INREF) programme "Towards Environmentally Sustainable and Equitable Palm Oil: promoting sustainable pathways by exploring connections between flows, networks and systems at multiple levels" funded by Wageningen University, The Netherlands. The research has been conducted in collaboration with 
University of Riau. We like to thank the manager of scheme smallholders and farmers for sharing their information.

\section{REFERENCES}

Aidoo, R., \& Fromm, I. (2015). Willingness to Adopt Certifications and Sustainable Production Methods among Small-Scale Cocoa Farmers in the Ashanti Region of Ghana. Journal of Sustainable Development, 8(1): 33-43.

Amekawa, Y. (2010). Rethinking Sustainable Agriculture in Thailand: A Governance Perspective. Journal of Sustainable Agriculture, 34(4): 389-416. doi: 10.1080/10440041003680254

Arifin, B. (2016). Roles of Commodities in Poverty Alleviation and Strengthening Landscape Management: Towards Sustainability Advantage. Paper presented at the Workshop Perencanaan Tataguna Lahan dan Pengelolaan Sumberdaya Alam, Kementerian Koordinator bidang Perekonomian dan CIFOR, 26 April 2016. Jakarta.

Bacon, C. (2005). Confronting the Coffee Crisis: Can Fair Trade, Organic, and Specialty Coffees Reduce Small-Scale Farmer Vulnerability in Northern Nicaragua? World
Development, 33(3): 497-511. doi: 10.1016/j.worlddev.2004.10.002

Bacon, C. M., Méndez, V. E., Gómez, M. E. F., Stuart, D., \& Flores, S. R. D. (2008). Are sustainable coffee certifications enough to secure farmers livelihoods? The millenium development goals and Nicaragua's fair trade cooperatives. Globalizations, 5(2): 259-274. doi: 10.1080/14747730802057688

Barham, B. L., Callenes, M., Gitter, S., Lewis, J., \& Weber, J. (2011). Fair Trade/Organic Coffee, Rural Livelihoods, and the "Agrarian Question": Southern Mexican Coffee Families in Transition. World Development, 39(1): 134-145.

Barham, B. L., \& Weber, J. G. (2012). The Economic Sustainability of Certified Coffee: Recent Evidence from Mexico and Peru. World Development, 40(6): 1269-1279. doi: 10.1016/j.worlddev.2011.11.005

Beuchelt, T. D., \& Zeller, M. (2011). Profits and poverty: Certification's troubled link for Nicaragua's organic and fairtrade coffee producers. [Special Section: Ecological Economics and Environmental History]. Ecological Economics, 70(7): 1316-1324. doi: 10.1016/j.ecolecon.2011.01.005 
Bitzer, V., Glasbergen, P., \& Arts, B. (2013). Exploring the potential of intersectoral partnerships to improve the position of farmers in global agrifood chains: findings from the coffee sector in Peru. Agriculture and Human Values, 30(1): 5-20. doi: 10.1007/s10460-012-9372-z

Blackman, A., \& Jorge, R. (2011). Producerlevel benefits of sustainability certification. Conservation Biology, 25(6): 1176-1185. doi: 10.1111/j.1523-1739.2011.01774.x

Brandi, C., Cabani, T., Hosang, C., Schirmbeck, S., Westermann, L., \& Wiese, H. (2015). Sustainability Standards for Palm Oil: Challenges for Smallholder Certification Under the RSPO. Journal of Environment \& Development, 24(3): 292.

Calil, D. (2013). Oil palm smallholders' willingness to pay for RSPO certification (Case study in Riau and Jambi, Indonesia). Paper presented at the RT 11 RSPO, 11-14 November 2013. RSPO, Medan.

Christin, S., Hutabarat, S., \& Dewi, N. (2015). Keragaan Petani Kelapa Sawit Pola KKPA dalam Menghadapi Sertifikasi di Desa Bina Baru Kecamatan Kampar Kiri Tengah, Kabupaten Kampar. Jurnal Online
Mahasiswa Fakultas Pertanian

Universitas Riau, 2(1): 1-12.

FAO. (2014). Impact of international voluntary standards on smallholder market participation in developing countries: A review of the literature. Agribusiness and Food Industries Series.

Gawron, J.-C., \& Theuvsen, L. (2010). Agrifood certification schemes in an intercultural context: Theoretical reasoning and empirical findings. Food Economics Acta Agriculturae Scandinavica, Section C, 7(2-4): 209-221. doi: 10.1080/16507541.2010.531944

Gockowski, J., Afari-Sefa, V., Sarpong, D. B., Osei-Asare, Y. B., \& Agyeman, N. F. (2013). Improving the productivity and income of Ghanaian cocoa farmers while maintaining environmental services: what role for certification? International Journal of Agricultural Sustainability, 11(4): 331-346. doi: 10.1080/14735903.2013.772714

Harianja, K., Hutabarat, S., \& Dewi, N. (2015). Analisis Persepsi Petani Kelapa Sawit Pola Swadaya Menghadapi Sertifikasi RSPO di Kecamatan Ukui, Kabupaten Pelalawan. Jurnal Online Mahasiswa Fakultas Pertanian Universitas Riau, 2(1): 1-13. 
Hidayat, N. K., Glasbergen, P., \& Offemans, A. (2015). Sustainability Certification and Palm Oil Smallholders' Livelihood: A Comparison between Scheme Smallholders and Independent Smallholders in Indonesia. International Food and Agribusiness Management Review, 18(3): 25-48.

Hutabarat, S., Slingerland, M., \& Dries, L. (2017). The prospects and challenges of certification for different types of oil palm smallholders. in Progress.

Hutabarat, S., Slingerland, M., Rietberg, P., \& Dries, L. (2017). Costs and benefits of certification of independent smallholders. Submitted.

Kaminski, J., Headey, D., \& Bernard, T. (2011). The Burkinabè Cotton Story 1992-2007: Sustainable Success or Sub-Saharan Mirage? World Development, 39(8): 1460-1475.

Kuwornu, J. K. M., Nafeo, A. A., \& OseiAsare, Y. B. (2013). Financial Viability, Value Addition and ConstraintAnalyses of Certified Organic Pineapple Production and Marketing in Ghana. African Journal of Basic \& Applied Sciences, 5(1): 12-24.

Lee, J. S. H., Ghazoul, J., Obidzinski, K., \& Koh, L. P. (2014). Oil palm smallholder yields and incomes constrained by harvesting practices and type of smallholder management in Indonesia. Oil palm smallholder yields and incomes constrained by harvesting practices and type of smallholder management in Indonesia, 34(2): 501-513.

Lee, J. S. H., Rist, L., Obidzinski, K., Ghazoul, J., \& Koh, L. P. (2011). No farmer left behind in sustainable biofuel production. Biological Conservation, 144(10): 2512-2516.

Lemeilleur, S. (2013). Smallholder compliance with private standard certification: the case of GlobalGAP adoption by mango producers in Peru. International Food and Agribusiness Management Review, 16(4): 159-180.

Makita, R. (2012). Fair Trade and organic initiatives confronted with Bt cotton in Andhra Pradesh, India: A paradox. [Themed issue: Spatialities of Ageing]. Geoforum, 43(6): 12321241.

Manggabarani, A. (2009). Palm Oil: A Golden Gift From Indonesia to the World. Directorate General of Estate Crops in Colaboration with Sinar Mas, Jakarta. 102p.

Ouma, S. (2010). Global standards, local realities: private agrifood governance 
and the restructuring of the Kenyan horticulture industry. Economic Geography, 86(2): 197-222. doi: 10.1111/j.1944-8287.2009.01065.x

Prodinger, B., Rudman, D. L., \& Shaw, L. (2015). Institutional ethnography: studying the situated nature of human occupation. Journal of Occupational Science, 22(1): 71-81.

Raynolds, L., Murray, D., \& Heller, A. (2007). Regulating sustainability in the coffee sector: A comparative analysis of third-party environmental and social certification initiatives. Agriculture and Human Values, 24(2): 147-163. doi: 10.1007/s10460006-9047-8

Silva-Castaneda, L. (2012). A forest of evidence: third-party certification and multiple forms of proof-a case study of oil palm plantations in
Indonesia. [Article]. Agriculture and Human Values, 29(3): 361-370. doi: 10.1007/s10460-012-9358-x

Suharni, Waluyati, L. R., \& Jamhari. (2017). The Application of Good Agriculture Practices (GAP) of Shallot in Bantul Regency. Jurnal Agro Ekonomi, 28(1): 48-63.

Weber, J. G. (2011). How much more do growers receive for Fair Tradeorganic coffee? Food Policy, 36(5): 678-685. doi: 10.1016/j. foodpol.2011.05.007

Wijaya,A., \& Glasbergen, P. (2016). Toward a New Scenario in Agricultural Sustainability Certification? The Response of the Indonesian National Government to Private Certification. The Journal of Environment \& Development, 25(2): 219-246. doi: $10.1177 / 1070496516640857$ 